\begin{tabular}{|c|c|c|}
\hline Beitr. Ent. & Keltern & ISSN 0005-805X \\
\hline $\mathbf{5 9}(2009) 2$ & S. $489-512$ & 15.12 .2009 \\
\hline
\end{tabular}

\title{
New or poorly known Tineidae from Mauretania, Morocco, Algeria, and Tunisia
}

\section{(Lepidoptera)}

With 41 figures

\author{
ReinhaRd GaEdike
}

\section{Summary}

As the result of the study of tineid material, which was collected in Mauretania, Morocco, Algeria and Tunisia, four species are newly recorded from North Africa (Morophaga choragella (Denis \& SCHIfFermüller, 1775), Nemapogon sardica Gaedike, 1983, Nemapogon picarella (ClerCK, 1759), Cephimallota crassiflavella Bruand, 1851); two species, (Infurcitinea marcunella (Rebel, 1901), Crassicornella agenjoi (Petersen, 1957)) are newly recorded from Mauretania, four species (Neurothaumasia ankerella (MANN, 1867), Elatobia fuliginosella (Lienig \& Zeller, 1846), Anomalotinea paepalella (Walsingham, 1907), Trichophaga tapetzella (Linnaeus, 1758)) are newly recorded from Morocco; seven species (Rhodobates unicolor (STAudinger, 1870), Eudarcia nigraella (Mariani, 1937), Infurcitinea lambessella Petersen, 1958, Stenoptinea cyaneimarmorella (Millère, 1844), Elatobia fuliginosella (Lienig \& ZELler, 1846), Trichophaga tapetzella (Linnaeus, 1758), Proterospastis autochthones (Walsingham, 1907)) are newly recorded from Tunisia. The six species (Infurcitinea maura Petersen, 1962, Infurcitinea lambessella Petersen, 1958, Infurcitinea incertula (Meyrick, 1928), Reisserita chalcopterella (Zerny, 1935), Reisserita luteopterella Petersen, 1957, Anomalotinea cubiculella romei (Turati, 1930)) are recorded from material other than the types for the first time. A female of Crassicornella zernyi (Petersen, 1957) is recorded for the first time, and Catabola atlantis Zagulajev, 1975 is established as a new synonym of C. zernyi. The following taxa are described as new: Nemapogon algerica sp. n., Infurcitinea italicoides sp. n., Reisserita bettagi sp. n., Reisserita stengeli sp. n., Reisserita karsholti sp. n., Anomalotinea wernoi sp. n., Anomalotinea derrai sp. n., and Amphixystis maroccana sp. $\mathbf{n}$. A checklist of species, at present known from Mauretania, Morocco, Algeria and Tunisia is given.

\section{Zusammenfassung}

Im Ergebnis der Untersuchung von Tineiden-Material, welches in Mauretanien, Marokko, Algerien und Tunesien gesammelt wurde, konnten für Nordafrika vier Arten (Morophaga choragella (Denis \& Schiffermüller, 1775), Nemapogon sardica Gaedike, 1983, Nemapogon picarella (Clerck, 1759), Cephimallota crassiflavella BRUAND, 1851), für Mauretanien zwei Arten (Infurcitinea marcunella (ReBeL, 1901), Crassicornella agenjoi (Petersen, 1957)), für Marokko vier Arten (Neurothaumasia ankerella (MANN, 1867), Elatobia fuliginosella (Lienig \& Zeller, 1846), 1846) Anomalotinea paepalella (WAlsingham, 1907), Trichophaga tapetzella (Linnaeus, 1758)), für Tunesien sieben Arten (Rhodobates unicolor (STAUdinger, 1870), Eudarcia nigraella (Mariani, 1937), Infurcitinea lambessella Petersen, 1958, Stenoptinea cyaneimarmorella (Millière, 1844), Elatobia fuliginosella (Lienig \& Zeller, Trichophaga tapetzella (Linnaeus, 1758), Proterospastis autochthones (Walsingham, 1907)) nachgewiesen werden. Die sechs Arten Infurcitinea maura Petersen, 1962, Infurcitinea lambessella Petersen, 1958, Infurcitinea incertula (Meyrick, 1928), Reisserita chalcopterella (Zerny, 1935), Reisserita luteopterella Petersen, 1957, Anomalotinea cubiculella romei (Turati, 1930) wurden erstmals nach den Typenfunden festgestellt. Von Crassicornella zernyi (Petersen, 
1957) konnte das Weibchen erstmals nachgewiesen werden, Catabola atlantis ZAGULAJev, 1975 wird als neues Synonym von C. zernyi angesehen. Die folgenden Arten werden als neu beschrieben: Nemapogon algerica sp. n., Infurcitinea italicoides sp. n., Reisserita bettagi sp. n., Reisserita stengeli sp. n., Reisserita karsholti sp. n., Anomalotinea wernoi sp. n., Anomalotinea derrai sp. n., and Amphixystis maroccana sp. n. Es wird eine Checkliste der bisher aus den Ländern Mauretanien, Marokko, Algerien und Tunesien nachgewiesenen Arten zusammengestellt.

\section{Key words}

Mauretania, Morocco, Algeria, Tunisia; new records; new species; new synonymy.

\section{Introduction}

During the past few years it was possible for me, through the courtesy of several colleagues, to study many tineids from the countries mentioned above. As a result it is possible to present first records for North Africa, first country records, and some new records for species previously only known from types. Additionally, eight new species are established, which are described below. The studied material is deposited in various museums or in the private collections of the collectors.

The checklist provides an overview of present knowledge of the Tineidae in the four countries here studied, based on material checked in the last 50 years by G. Petersen and myself.

The ink drawings of the genitalia were made at different magnifications. The scale line accompanying each drawing represents $0.5 \mathrm{~mm}$.

\section{Abbreviations}

The abbreviations of the institutional collections, in which the material studied is deposited, follow the list "Insect and Spider Collections of the World" from the Bishop Museum/Honolulu (http: //hbs.bishopmuseum.org/codens).

\begin{tabular}{|c|c|}
\hline Coll. Baldizzone & Giorgio Baldizzone/Italy: Asti \\
\hline Coll. Bassi & GraZiano Bassi/Italy: Torino \\
\hline Coll. Bettag & ERICH BetTAG/Germany: Dudenhofen \\
\hline Coll. Derra & Georg Derra/Germany: Reckendorf \\
\hline Coll. Keller & Rudolf Keller/Germany: Sulzemoos \\
\hline Coll. Meyer & Marc Meyer/Germany: Perl-Kesslingen \\
\hline Coll. RetzlafF & HANS RetZlafF/Germany: Lage \\
\hline Coll. STÜBNER & ANDREAS STÜBner/Germany: Jänschwalde-Ost \\
\hline Coll. Werno & ANDREAS WERNo/Germany: Nunkirchen \\
\hline BMNH & United Kingdom, London, The Natural History Museum \\
\hline DEI & Germany, Müncheberg, Senckenberg Deutsches Entomologisches Institut \\
\hline ISZP & Poland, Krakow, Polish Academy of Sciences, Institute of Systematic Zoology \\
\hline MNHN & France, Paris, Muséum National d'Histoire Naturelle \\
\hline ZIN & Russia, St. Petersburg, Russian Academy of Sciences, Zoological Institute \\
\hline ZMHB & Germany, Berlin, Museum für Naturkunde der Humboldt-Universität \\
\hline ZMUC & $\begin{array}{l}\text { Denmark, København [= Copenhagen], University of Copenhagen, Zoological } \\
\text { Museum }\end{array}$ \\
\hline
\end{tabular}


Acknowledgments

I am thankful to my colleagues for the courtesy which make it possible for me to study the tineid material. Special thanks to Christian Kutzscher for making colour pictures, and to Andrew Liston for linguistic corrections.

\section{Systematics}

\section{Rhodobates unicolor (STAUDINGER, 1870)}

Tunisia: $1 \sigma^{\star}, 40$ km südl. Tunis, 29.ix.2007, leg. B. Sснаснт; Coll. StüBner; 1 o $^{\star}$, Prov. Nabeul, Umg. Soliman, Borj-Cedria, 5.x.2007; leg. B. Sснаснт; DEI: New country records.

\section{Morophaga choragella (DENIS \& SCHIFFERMÜLLER, 1775)}

Morocco: 1 , Mittl. Atlas, Ifrane, 22.v.1997, leg. SAKsida, Coll. Keller; Tunisia: 1 , Maknassy, 28.viii.1937, MNHN: First records for North Africa.

\section{Nemapogon algerica sp. $\mathbf{n}$.}

\section{Material:}

Holotype ơ, "Museum Paris, Algérie Edough, P. Lesne 1908” [printed label]; “10. 08”[handwritten label]; "Tinea cloacella Hw."[handwritten label]; "Gen.präp. [genitalia slide] GaEdike NR. 6337”; "Holotypus Nemapogon algerica sp. n. det. R. GaEdike 2009”; MNHN.

Paratypes: 1 i with the same dates, on the same stage; MNHN; $10^{7}$, "Museum Paris, Algérie Edough, P. Lesne 1908” [printed label]; “oct. [19]08”[handwritten label]; “Gen.präp. [genitalia slide] Gaedike NR. 6264”; "Paratypus Nemapogon algerica sp. n. det. R. Gaedike 2009”; DEI.

\section{Description (Fig. 1):}

Wingspan 12-13 mm; head creamy, laterally darker, palpi inside creamy, outside darker, second segment with some outwards-directed bristles; legs inside creamy, outside darker, tips of tarsal segments also creamy; thorax creamy, overlaid with numerous grey-brown scales, tegulae dark grey-brown, apex lighter; forewing with the pattern of dark brown and brown patches and stripes, characteristic for the genus: at $1 / 2$ an oblique dark brown band, nearly reaching dorsum, the second half lighter brown, from $1 / 2$ to apex costa with five short dark brown stripes; fringes creamy, with a dark brown line; the apical half of forewing overlaid with dark and light brown patches; hindwing white.

Male genitalia (Figs 9-12): Uncus broad, apically cut; gnathos arms after the first third bent, with a long pointed spur-shaped processus, the distal part narrower as the proximal part, with curved tip; saccus short; valve with pointed tip, the bristled digitus on valva with enlarged rounded tip, anellus with two blunt tips, basally rounded; phallus two times longer than valva, after $1 / 2$ with a break, the distal part more strongly sclerotized than basal part, with broad tooth-like lateral processus, the shape is variable (see Fig. 12).

Female genitalia (Figs 13-14): Eighth tergite proximally with short narrow apophysae-like sclerotizations; ostium convex, curved distally, laterally edged, more strongly sclerotized than other parts, funnel-shaped, antrum also more strongly sclerotized; in ductus bursae at $1 / 2$ of the length 
an area with some rows of scale-shaped sclerotization, hardly more strongly sclerotized than the other ductus.

Life history: Unknown.

Etymology: Named after the country in which the specimens were collected.

\section{Remarks:}

The general structure of male genitalia is characteristic for the genus, but the shape of the gnathos arms differs from all other known species, phallus with the tooth-like lateral sclerotization and the break at $1 / 2$. In female genitalia the shape of ostium is similar to several species of the gravosaella-group.

\section{Nemapogon sardica GAEDIKE, 1983}

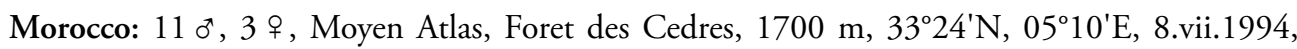
leg. Stengel; Coll. Derra DEI; 1 क , Mittlerer Atlas, Mischliffen, 2000 m, 29.vii.1993, leg. Stengel; Coll. Derra; 1 , H. Atlas, Zeida near Boumia, 1400 m, 7.viii.1997, leg. et Coll. Bettag; Algeria: 1 ㅇ, Prov. Oran, Sidi-bel-Abbes, 17.vi.1916, leg. Rotrou, genitalia slide no. 12196 (erroneously indicated as Nemapogon levantina Petersen, 1961 by Robinson (1980); BMNH; Tunisia: 1 , Ain Draham area, 5. - 18.v.1988, Zool. Mus. Copenhagen Exp.; ZMUC; 1 ․ Tabarka area, 7. - 18.v.1988, Zool. Mus. Copenhagen Exp.; ZMUC; 1 ㅇ, Lagh'Ghad..., 17.viii.1919, leg. C. Dumont; MNHN: First records for North Africa.

\section{Nemapogon picarella (CLERCK, 1759)}

Morocco: 1 ㅇ, Ifrane, Mn. Atlas, 1650 m, 15. - 30.vi.1939, leg. C. RunGs; MNHN: First record for North Africa. More material is needed to verify this distribution, because the species was hitherto known only from Europe and from the eastern part of Palaearctic, though, the Ifrane area has biotope (forests), in which this species could occur.

\section{Neurothaumasia ankerella (MANN, 1867)}

Morocco: 4 ơ, Rabat, Forêt de Mamora, 25. - 26.iv.1989, Exp. Mus. Copenhagen; ZMUC: New country record.

\section{Eudarcia nigraella (MARIANI, 1937)}

Tunisia: 1 o $^{\star} 1$ ㅇ Tabarka, ex 1. 15., 17.vi.1975, leg. H. Retzlaff; Coll. Retzlaff: New country record.

\section{Remarks:}

There were given no information about the substratum, on which was bred these specimens. 


\section{Infurcitinea maura Petersen, 1962}

Morocco: 1 ơ $^{\star}$ Rabat, Forêt de Mamora, 25. - 26.iv.1989, Exp. Mus.Copenhagen; ZMUC: First record other than type series.

\section{Infurcitinea lambessella Petersen, 1958}

Tunisia: $20^{\star}$, Ain Draham area, 5. - 18.v.1988, Zool. Mus. Copenhagen Exp.; ZMUC: New country record, first record other than type series.

\section{Infurcitinea marcunella (REBEL, 1901)}

Mauretania: $1 \sigma^{\star}$, Mauretania, 1887, leg. STAUdinger; ISZP: New record for the country.

\section{Infurcitinea italicoides sp. $\mathbf{n}$.}

\section{Material:}

Holotype o "Marokko, Imili Straßenrand [roadside], 31 $09^{\circ} 45^{\prime}$ - 0755'49", Lichtfang [lux] 19.05.2005, leg. Andreas Werno"; "Gen. präp. [genitalia slide] Gaed.[IKe] Nr. 5356”; "Holotypus ơ Infurcitinea italicoides sp. n. det. R. Gaedike 2008”; Coll. Werno.

Paratypes: $20^{\star}, 1$ specimen without abdomen "Marokko, Westlich Anezi Straßenrand [roadside], 2940'09" - 09'27'32", Lichtfang [lux], 17.05.2005, leg. Andreas Werno (one specimen with genitalia slide Nr. 5345); "Paratypus ơ Infurcitinea italicoides sp. n. det. R. GAEDIKE 2008"; Coll. Werno; DEI; $20^{\star}$ "Marokko, Arbaa Sahel, 29³6'46" - 0954'20", Lichtfang [lux], 14.05.2005, leg. Andreas Werno (one specimen with genitalia slide Nr. 6185)"; "Paratypus ơ Infurcitinea italicoides sp. n. det. R. Gaedike 2008”; Coll. Werno; DEI.

\section{Description (Fig. 2):}

Wingspan $8 \mathrm{~mm}$; Head brush cream-coloured, from neck to basis of antennae dark brown, clearly separated from the cream-coloured region; antennae dark brown on the dorsal site, ventrally cream-coloured; labial palpi outside brown, inside cream-coloured; thorax cream-coloured, tegulae brown; fore- and middlelegs outside brown with cream-coloured rings on apical ends of segments, inside unicolorous cream-coloured, hindlegs cream-coloured, without brown; forewing cream-coloured, with brown pattern: brown are the basal area, two stripes at $1 / 2$ and $2 / 3$, and a patch before apex; fringe cream-coloured; hindwing light cream-coloured.

Male genitalia (Figs 15-16). Uncus rounded, tegumen narrow, vinculum broad, apically bent into two rounded tips, basally with two short rounded processi; valva with long transtilla and broad basal part, costal part broad apically somewhat enlarged, with blunt tip, ventral part folded, with a rounded cloth-shaped appendix; anellus with two very long arms, basally narrow, distally somewhat broader, from second half of length with numerous pointed bristles, closely connected with phallus.

Female genitalia. Unknown.

Life history: Unknown.

Etymology: The name refers to the similarity in the shape of genitalia with Infurcitinea italica (AMSEL, 1954). 


\section{Remarks:}

The new species belongs to group of species with anellus with two long bristled arms (media (Walsingham, 1907), italica (Amsel, 1954), cyprica Petersen \& Gaedike, 1985). The shape of valva is quite different in media and cyprica, valva of italica differs by having an apically narrower costal arm, additionally the arms of anellus are bifurcate.

\section{Infurcitinea incertula (MEYRICK, 1928)}

Morocco: 1 q , Taroudanut, 21.v.1986, leg. Curletti, Coll. Baldizzone: First record other than type series.

\section{Stenoptinea cyaneimarmorella (MILLIÈRE, 1854)}

Tunisia: $1 \mathrm{o}^{\star}$, Prov. Nabeul, Umg. Soliman, Borj-Cedria, 5.x.2007, leg. B. Schacht, Coll. STÜBNER: New country record.

\section{Cephimallota crassiflavella BRUAND, 1851}

Algeria: $1 o^{\star}, 1$ ㅇ , Alger, Aout 1907; MNHN; $1 o^{\star}$, Algérie, St. Charles, A. Théry; MNHN: New record for North Africa.

\section{Crassicornella agenjoi (PETERSEN, 1957)}

Mauretania: $2{ }^{\star}$, Mauretania, 1887, leg. STAUdINGER; ISZP. New country record.

\section{Crassicornella zernyi (Petersen, 1957)}

Catabola atlantis Zagulajev, 1975: 291, syn. nov.

Morocco: 4 o 1 1 , Prov. Agadir, Tarhazuote, 10. - 19.iv.1990, leg. Bassi/Olmi/Scaramozzino, Coll. Bassi.

The material allows the first description of the female genitalia (Figs 17-18):

Posterior apophyses near the papillae analis with bristled bulge, characteristic for the tribe, the two branches of the anterior apophyses widened, bristled, area around ostium band-shaped; ductus bursae with shell-shaped sclerotization, in the middle with hanging cone-shaped sclerotization. This is the third species in the genus, of which females are now known.

The comparison of the description and drawing of male genitalia of Catabola atlantis, described by Zagulajev (1975) from "Marokko, Gr. Atlas, Tachdirt, 2200-2900 m, 11.-19. VII. [19]33, leg. ZERNY" [slide 11045], Coll. ZIN, shows unequivocally that these species are identical. Catabola atlantis ZAGUlajev, 1975 is accordingly a new synonym of Crassicornella zernyi (Petersen, 1957).

\section{Reisserita bettagi sp. n.}

\section{Material:}

Holotype, o* "Marokko, Moyen Atlas Ifrane Umgeb. 1600 m, 11. - 22.06.1996, leg. E. BetTaG;" "Gen. präp. [genitalia slide] Gaedike NR.: 5768;" "Holotypus ơ , Reisserita bettagi sp. n. det. R. Gaedike 2008;” Coll. Bettag. 


\section{Description (Fig. 3):}

Wingspan $12 \mathrm{~mm}$; Head brush, mainly rubbed, light brown, scapus outside dark brown, inside light brown, flagellum ringed; thorax and forewing unicolourous light brown, without any pattern, hindwing dark grey.

Male genitalia (Figs 19-22). Uncus bilobate, with blunt tips, gnathos arms stout, basally broad, the last third curved, with pointed tip; vinculum broad, saccus with rounded tip, nearly triangular; valva with long, more strongly sclerotized transtilla, basally rounded, costal edge convex, from the last third directed ventrally, with rounded tip, ventral edge concave; phallus as long as the whole genitalia, narrow, with two hook-shaped cornuti.

Female genitalia. Unknown.

Life history: Unknown.

Etymology: Named in honour of the collector, Mr. ERICH BetTaG.

\section{Remarks:}

There is a small similarity with $R$. zernyi Petersen, 1957 in the shape of the valva with convex costal edge and concave ventral edge, but the shape of uncus and the phallus with only two cornuti clearly differentiates the new species.

\section{Reisserita stengeli sp. n.}

\section{Material:}

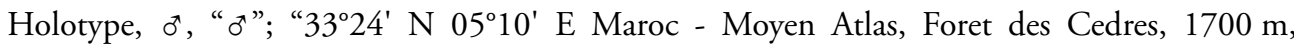
8.vii.1994, leg. Stengel”; "[genitalia slide G. Derra] 6302”; "Holotypus ơ, Reisserita stengeli sp. n. det. R. Gaedike 2009;" Coll. Derra.

\section{Description (Fig. 4):}

Wingspan $16 \mathrm{~mm}$; head yellowish clay-coloured, outside of labial palpi and antenna somewhat darker; thorax the same colouration, base of tegulae somewhat darker; forewing also clay-coloured, with scattered darker scales, costa somewhat darker, hindwing light grey.

Male genitalia (Figs 23-24). Uncus incised in the middle, gnathos arms long, nearly circularly bent, with pointed tip; saccus very long, narrow, valva nearly as long as saccus, nearly parallel, from base to rounded tip valve becomes narrower, ventral edge convex; phallus longer than saccus, with a row of appr. 10 short thorn-like cornuti.

Female genitalia. Unknown.

Life history: Unknown.

Etymology: Named in honour of the collector, Mr. STENGEL.

\section{Remarks:}

Superficially similar to other members of the genus, but structure of genitalia shows distinct differences. The size of valvae is similar to chalcopterella, but the very long saccus, the circularly bent gnathos arms, and presence of only one row of cornuti are clear differences. 


\section{Reisserita chalcopterella (ZERNY, 1935)}

\section{Morocco:}

$1 \mathrm{o}^{\star}$, H. Atlas, Oukaimeden, 2650 m, 12.viii.1997, lux, leg. et Coll. Bettag: First record other than the type.

Examination of this specimen resulted in a more detailed study of the variability in the genitalia. Figures 25-27 shows the various shapes of valvae, especially the size of the small tooth on the ventral edge.

\section{Reisserita luteopterella PETERSEN, 1957}

Morocco: 1 ơ $^{\star}$, Arbaa Sahel, 29³6'46" 0954'20" 14. 5. 2005, leg. et Coll. Werno: First record other than the typical series.

\section{Reisserita karsholti sp. n.}

\section{Material:}

Holotype, ơ "Morocco, 25 km S Essaouira Sidi Kaould, 100 m, 28.iii.2005 O. Karsholt"; "Coll. ZMUC Copenhagen Denmark"; "Gen. präp. [genitalia slide] GaEdike NR: 6181"; "Holotypus o Reisserita karsholti sp. n. det. R. GAEDIKe 2008”; ZMUC.

\section{Description (Fig. 5):}

Wingspan $15 \mathrm{~mm}$; head brush clay-coloured, antenna dark grey, labial palp light clay-coloured, second segment with numerous long dark brown bristles; thorax and forewing clay-coloured, without any pattern; hindwing grey.

Male genitalia (Figs 28-31). Uncus broad at basis, proximally with V-shaped incision, two pointed tips; gnathos arms strong, with clearly developed knee-shaped processus ventrally, dorsally at $1 / 3$ bent, with pointed tip; tegumen broad, edged; vinculum large, triangular, on each side at $1 / 2$ with a small hook-shaped processus (insertion of transtilla); valva nearly parallel, dorsal edge straight, ventral edge at $1 / 2$ convex, with rounded tip, transtilla nearly as long as valva; phallus longer than uncus+tegumen, thin, with two small cornuti.

Female genitalia. Unknown.

Life history: Unknown.

Etymology: Named in honour to the collector, Ole Karsholt.

\section{Remarks:}

The new species is superficially similar to zernyi Petersen, 1957, but the shape of genitalia is clearly different (incision on uncus V-shaped, shape of gnathos arms, shape of valva and the long transtilla, and the hook-shaped processi on vinculum).

\section{Anomalotinea paepalella (WALSINGHAM, 1907)}

Morocco: 3 o $^{\star}$, Maroc / Haut Atlas, Nord-Sahara, 1100 m, 40 km w. Ar-Rachidia, 27.iii.1995, leg. Stengel; Coll. Derra; DEI. New country record. 


\section{Anomalotinea wernoi sp. n.}

\section{Material:}

Holotype, ơ "Marokko ED Tinn Paßhöhe, Straßenrand [roadside], 2943'35" - 09¹6'33", Lichtfang 16.05.2005, leg. Andreas Werno;" "Gen. präp. [genitalia slide] Gaedike NR.: 5355;" "Holotypus o`, Anomalotinea wernoi sp. n. det. R. Gaedike 2008;" Coll. Werno.

Paratypes: $20^{\star}$, same location, one specimen with genitalia slide No. 5344; "Paratypus $\sigma^{*}$, Anomalotinea wernoi sp. n. det. R. Gaedike 2008;" Coll. Werno; DEI; 1 o", same location, but 17.05.2006; "Paratypus ơ, Anomalotinea wernoi sp. n. det. R. Gaedike 2008;" Coll. Werno.

\section{Description (Fig. 6):}

Wingspan $13 \mathrm{~mm}$; head brush clay-coloured, antenna dark grey, labial palp outside dark grey, inside cream-coloured, second segment with numerous dark bristles; fore- and midlegs grey-brown, overlaid with lighter scales, tips of the tarsal segments light cream-coloured, hindlegs clearly lighter; thorax and forewing clay-coloured; hindwing grey-brown.

Male genitalia (Figs 32-33). Uncus characteristic for the genus with pointed tip apically in the middle; gnathos arms strong, hook-shaped, the last third more curved, with pointed tip; vinculum broad, saccus long; valva with long transtilla, divided into a ventral and dorsal part, ventral part shorter than dorsal part, broader, blunt pointed, dorsal part narrower and longer than ventral part, with rounded tip; phallus as long as uncus+vinculum+saccus, wsith two cornuti, one of them hook-shaped, the other more straight.

Female genitalia. Unknown.

Life history: Unknown.

Etymology: Named in honour of ANDREAS WERnO, the collector.

\section{Remarks:}

The new species is superficially similar to some other members of the genus. The shape of the genitalia, especially the valva, divided into two parts is similar to derrai. Differences to derrai are the prolonged dorsal part of valva, with rounded tip and the broad, blunt pointed ventral part. Other differences are the stronger, more compact gnathos arms and phallus with one straight and only one hook-shaped cornutus.

\section{Anomalotinea derrai sp. n.}

\section{Material:}

Holotypus ơ, “历”; “[genitalia slide G. Derra] 5473”; "Marokko, Mittlerer Atlas, Mischliften, 2000 m, 29.x.1993, leg. Stengel”; "Holotypus ơ Anomalotinea derrai sp. n. det. R. Gaedike 2009”; Coll. Derra.

\section{Description (Fig. 7):}

Wingspan $14 \mathrm{~mm}$; head creamy, scales proximally lighter than apically, labial palpi outside browngrey, inside nearly white, scapus creamy, mixed with darker scales, flagellum dark; thorax sandcoloured with light pink shimmer; forewing with the same colouration; hindwing grey.

Male genitalia (Figs 34-36). Uncus characteristic for the genus with pointed tip apically in the middle; gnathos arms after $1 / 2$ hook-shaped, subapically with very small thorns; saccus long, 
broad, bluntly pointed; valva with long transtilla, divided into a nearly rounded ventral and a longer dorsal part, edged on the basal side, the dorsal part apically somewhat broader than base, rounded, with a short nose-shaped tip ventrally; phallus somewhat longer as saccus, narrow, with two hook-shaped cornuti.

Female genitalia. Unknown.

Life history: Unknown.

Etymology: Named in honour of Georg Derra, who made it possible for me to study many interesting specimens from Morocco.

\section{Remarks:}

The light pink shimmer distuingishes superficially the new species from other members of the genus. The genitalia are similar to wernoi, but clear differences are the shape of valva with the rounded ventral part and the nose-shaped point of dorsal part, together with the thorned apical part of gnathos arms.

\section{Anomalotinea cubiculella romei (TuRATI, 1930)}

Tunisia: $1 \sigma^{\star}, 25 \mathrm{~km}$ S Feriana, Mejen Bel Abbès, 11.iii.1986, Zool. Mus. Copenhagen Exp.; ZMUC: First record other than type.

\section{Trichophaga tapetzella (LINNAEUs, 1758)}

Algeria: $1 \sigma^{\star}$, Prov. D’Oran, Sidi-bel-Abbès, 1919, leg. Rotran;

Tunisia: $1 \sigma^{\star}, 15$ km E Tabarka, 20. - 25.iii.1986, Exp. Mus. Copenhagen, ZMUC: New country records.

\section{Elatobia fuliginosella (LIENIG \& ZELLER, 1846)}

Morocco: $10^{\star}$, dint. Khentira, 1.v.1990, leg. Bassi, Olmi \& Scaramozzino, Coll. Bassi; 1 q, Rabat, Forêt de Mamora, 25. - 26.iv.1989, Exp. Mus. Copenhagen, ZMUC;

Tunisia: 1 , Ain Draham area, 5. - 18.v.1988, Zool. Mus. Copenhagen Exp., ZMUC; 1 , Tabarka, 25.vii. - 3.viii.1995, leg. W. MeY; ZMHB: New country records.

\section{Proterospastis autochthones (Walsingham, 1907)}

Tunisia: $1 \sigma^{\star}$, Tunisie, C. Dumont; MNHN: New country record.

\section{Amphixystis maroccana sp. n.}

\section{Material:}

Holotype, ơ "Morocco, 8 km S Sidi Ifni, 20.iii.2005, 50 m, O. Karsholt"; "Coll. ZMUC Copenhagen Denmark"; "Gen. präp. [genitalia slide] GaEdike NR: 6180”; "Holotypus o Amphixystis maroccana sp. n. det. R. GAEDIKe 2008”; ZMUC. 


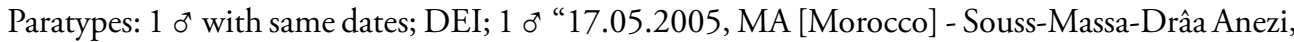
10 km W, M004-9,45897 / 29.66919, 800 m, lum. act. leg. Meyer M.”; “Gen. präp. [genitalia slide] Gaedike NR: 5579"; "Paratypus ơ Amphixystis maroccana sp. n. det. R. Gaedike 2008”; Coll. Meyer; $20^{\star}$, "Marokko, Imlil, Straßenrand [roadside] - 31 ${ }^{\circ} 09^{\prime} 45^{\prime \prime}$ - 0755'49", Lichtfang [lux], 19.05.2005, leg. Andreas Werno (one specimen with genitalia slide Gaedike NR: 6532)"; "Paratypus ơ Amphixystis maroccana sp. n. det. R. Gaedike 2009"; Coll. Werno; DEI; $20^{*}$, "Marokko, Westlich Anezi - Straßenrand [roadside] - 2940'09" - 09²7'32" Lichtfang [lux], 17.05.2005, leg. Andreas Werno"; "Paratypus ơ Amphixystis maroccana sp. n. det. R. Gaedike 2009"; Coll. Werno; DEI; 1 ㅇ, with same dates, "Gen. präp. [genitalia slide] Gaedike NR: 6531"; Coll. Werno.

\section{Description (Fig. 8):}

Wingspan $13 \mathrm{~mm}$; head brush bi-coloured: from insertion of antennae to palpi dark grey, the other part light cream-coloured; antenna dark grey, underside light cream-coloured; thorax also cream-coloured, tegulae dark brown, nearly black; forewing also bi-coloured: dorsum from basis to apex (with fringe) cream-coloured, the other part of wing dark brown, nearly black, the border uneven, but distinct; hindwing grey.

Male genitalia (Figs 37-39). Uncus with two long slightly curved, more strongly sclerotized socii, with pointed tip, apical edge more strongly sclerotized, tegumen broad, vinculum narrow, saccus long and thin; valva as long as uncus+tegumen, with short transtilla, costal edge concave, ventral edge convex, parallel, apically rounded, ventral edge before $1 / 2$ with a more strongly sclerotized tooth; phallus nearly as long as valva, narrow, laterally before apex with some hook-shaped sclerotizations.

Female genitalia (Figs 40-41). Anterior apophyses forked, ventral branch connected in the middle with antrum; ductus bursae behind ostium enlarged for a short distance, somewhat more strongly sclerotized, first half of ductus with some very small thorns, in second half one area with larger thorns, before corpus bursae an area with many very small thorns.

Life history: Unknown.

Etymology: Named after the country in which the new species was collected.

\section{Remarks:}

The new species is the third member of the genus in the Palaearctic. Superficially it is similar to all other members of the genus, but the shape of phallus differentiates it from islamella (Turati, 1927) (recorded from Israel and Libya), from undosa (Walsingham, 1908) (recorded from Canary islands) and from the other known African species. In female genitalia the enlarged first part of ductus bursae distuinguishes the new species from islamella and undosa. 
Checklist of tineid moths, at present known from Mauretania, Morocco, Algeria and Tunisia

\begin{tabular}{|c|c|c|c|c|}
\hline Taxon & Maur. & Mor. & Alg. & Tun. \\
\hline 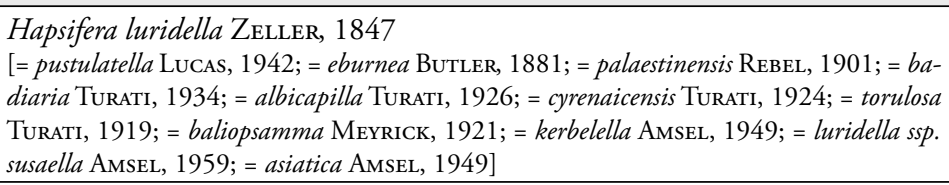 & - & - & - & $\mathrm{x}$ \\
\hline $\begin{array}{l}\text { Hapsifera multiguttella (RAGONOT, 1895) } \\
\text { [= jerichoella AmSEL, 1935; = maculata WALSINGHAM, 1907] }\end{array}$ & - & $\mathrm{x}$ & $\mathrm{x}$ & $\mathrm{x}$ \\
\hline $\begin{array}{l}\text { Rhodobates unicolor }(\text { STAUDINGER, 1870) } \\
{[=\text { tibulella } \text { REBEL, 1936] }}\end{array}$ & - & - & - & $\mathrm{x}$ \\
\hline Rhodobates friedeli PETERSEN, 1987 & - & $\mathrm{x}$ & - & - \\
\hline $\begin{array}{l}\text { Rhodobates algiricellus } \text { (REBEL, 1901) } \\
\text { [= hieratica } \text { TURATI, 1924; = chneouri LuCAS, 1942; = mauretanicus } \text { PETERSEN, 1958] }\end{array}$ & $\mathrm{x}$ & $\mathrm{x}$ & $\mathrm{x}$ & $\mathrm{x}$ \\
\hline $\begin{array}{l}\text { Morophaga morella } \text { (DUPONCHEL, 1838) } \\
{[=\text { morella f. fungicolella DuMONT, 1930] }}\end{array}$ & - & $\mathrm{x}$ & $\mathrm{x}$ & $\mathrm{x}$ \\
\hline $\begin{array}{l}\text { Morophaga choragella } \text { (Denis \& SCHIFFERMÜLLER, 1775) } \\
\text { [= boleti FABricius, } 1777 ;=\text { fungella } \text { THUnBERG, 1794; = mediella HüBNER, 1796] }\end{array}$ & - & $\mathrm{x}$ & - & $\mathrm{x}$ \\
\hline Nemapogon algerica sp. $\mathrm{n}$. & - & - & $\mathrm{x}$ & - \\
\hline $\begin{array}{l}\text { Nemapogon inconditella (LUCAS, 1956) } \\
\text { [= buckwelli LuCAS, 1956; = heydeni } \text { PeTERSEN, 1957; = thomasi CAPUSE, 1975; = hunga- } \\
\text { ricus CAPUSE, 1968, nec GOZMÁNY, 1960] }\end{array}$ & - & $\mathrm{x}$ & - & - \\
\hline $\begin{array}{l}\text { Nemapogon palmella (CHRÉTIEN, 1908) } \\
{[=\text { oueddarellus AMSEL, 1952] }}\end{array}$ & - & $\mathrm{x}$ & - & - \\
\hline Nemapogon sardica GAEDIKE, 1983 & - & $\mathrm{x}$ & $\mathrm{x}$ & $\mathrm{x}$ \\
\hline $\begin{array}{l}\text { Nemapogon picarella (CLERCK, 1759) } \\
\text { [= rigaella SODOFFSKY, 1830; = riganella ZELLER, 1839; = acerella TREITSCHKE, 1832] }\end{array}$ & - & $\mathrm{x}$ & - & - \\
\hline 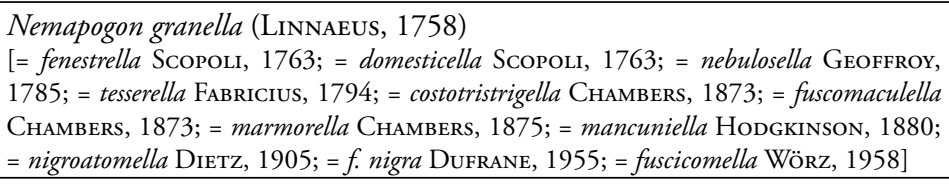 & - & $\mathrm{x}$ & $\mathrm{x}$ & - \\
\hline 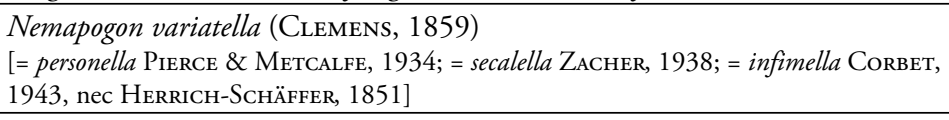 & - & $\mathrm{x}$ & $\mathrm{x}$ & - \\
\hline $\begin{array}{l}\text { Neurothaumasia ragusaella } \text { (WoCKe, 1889) } \\
\text { [= roeweri } \text { AMSEL, 1939; = africana GozmÁNY, 1960; = bifasciatella TURATI, 1924; = pu- } \\
\text { rella CHRÉTIEN, 1907] }\end{array}$ & - & $\mathrm{x}$ & - & $\mathrm{x}$ \\
\hline $\begin{array}{l}\text { Neurothaumasia ankerella }(\text { MANN, 1867) } \\
\text { [= burdigalensis LeMARCHAND, 1934; = tirsella AMSEL, 1952; = geratocoma WALSINGHAM, } \\
\text { 1907; = ankerella var. nigratella CHRÉTIEN, 1917] }\end{array}$ & - & $\mathrm{x}$ & $\mathrm{x}$ & - \\
\hline $\begin{array}{l}\text { Tenaga nigripunctella }(\mathrm{HaWORTH}, 1828) \\
\text { [= pomiliella } \text { Clemens, } 1862 ;=\text { moeniella } \text { RössLer, 1877; = linobola MeYRICK, 1893; } \\
=\text { sesquitertia } \text { MeYrick, } 1909]\end{array}$ & - & $\mathrm{x}$ & - & - \\
\hline $\begin{array}{l}\text { Eudarcia nigraella (MARIANI, 1937) } \\
\text { [= nigrella } \text { HARTIG, } 1939]\end{array}$ & - & - & - & $x$ \\
\hline $\begin{array}{l}\text { Infurcitinea nigropluviella }(\text { WalsINGHAM, 1907) } \\
{[=\text { maraschensis PETERSEN, 1968] }}\end{array}$ & - & - & $\mathrm{x}$ & $\mathrm{x}$ \\
\hline
\end{tabular}




\begin{tabular}{|c|c|c|c|c|}
\hline Taxon & Maur. & Mor. & Alg. & Tun. \\
\hline Infurcitinea maura Petersen, 1962 & - & $\mathrm{x}$ & - & - \\
\hline Infurcitinea marcunella (REBEL, 1901) & $\mathrm{x}$ & $\mathrm{x}$ & $\mathrm{x}$ & - \\
\hline Infurcitinea lambessella Petersen, 1958 & - & - & $\mathrm{x}$ & $\mathrm{x}$ \\
\hline $\begin{array}{l}\text { Infurcitinea frustigerella (WALSINGHAM, 1907) } \\
\text { [= absconditella CHRÉTIEN, 1915] }\end{array}$ & - & $\mathrm{x}$ & $\mathrm{x}$ & $\mathrm{x}$ \\
\hline Infurcitinea italicoides sp. $\mathrm{n}$. & - & $\mathrm{x}$ & - & - \\
\hline $\begin{array}{l}\text { Infurcitinea media (WALSINGHAM, 1907) } \\
\text { [= intricatella } \text { CHRÉTIEN, 1915] }\end{array}$ & - & - & $\mathrm{x}$ & $\mathrm{x}$ \\
\hline $\begin{array}{l}\text { Infurcitinea atrifasciella }(\text { STAUDINGER, 1870) } \\
{\left[=\text { diasi } \text { AMSEL, } 1957 ;=\text { zernyi } Z_{\text {AGULAJEV, }} 1974\right]}\end{array}$ & - & $\mathrm{x}$ & - & $\mathrm{x}$ \\
\hline Infurcitinea maroccana Petersen \& GaEdiKe, 1979 & - & $\mathrm{x}$ & - & - \\
\hline Infurcitinea senecai GAEDIKE, 1987 & - & - & - & $\mathrm{x}$ \\
\hline Infurcitinea incertula (MEYRICK, 1928) & - & $\mathrm{x}$ & - & - \\
\hline $\begin{array}{l}\text { Stenoptinea cyaneimarmorella (MILLIÈRE, 1854) } \\
\text { [= angustipennis HERRICH-SCHÄFFER, 1854; = angustipennis STAUDINGER, 1871] }\end{array}$ & - & - & $\mathrm{x}$ & $\mathrm{x}$ \\
\hline $\begin{array}{l}\text { Cephimallota crassiflavella BRUAND, } 1851 \\
\text { [= simplicella ZeLLER, 1852; = simplicella HeRRICH - SCHÄFFER, 1854] }\end{array}$ & - & - & $\mathrm{x}$ & - \\
\hline $\begin{array}{l}\text { Pachyarthra mediterranea (BAKER, 1894) } \\
\text { [= serotinella } \text { CHRÉTIEN, 1915; = pallidella LUCAS, 1933; = variegata LUCAS, 1950] }\end{array}$ & - & $\mathrm{x}$ & $\mathrm{x}$ & $\mathrm{x}$ \\
\hline Pachyarthra lividella (CHRÉTIEN, 1915) & - & $\mathrm{x}$ & $\mathrm{x}$ & $\mathrm{x}$ \\
\hline $\begin{array}{l}\text { Pachyarthra ochroplicella (CHRÉTIEN, 1915) } \\
\text { [= pentatma MEYRICK, 1937; = intermedia TURATI, 1930] }\end{array}$ & - & $\mathrm{x}$ & $\mathrm{x}$ & $\mathrm{x}$ \\
\hline Myrmecozela diacona Walsingham, 1907 & - & $\mathrm{x}$ & $\mathrm{x}$ & $\mathrm{x}$ \\
\hline $\begin{array}{l}\text { Myrmecozela ataxella (CHRÉTIEN, 1905) } \\
{[=\text { chneourella LuCAs, } 1950]}\end{array}$ & - & $\mathrm{x}$ & $\mathrm{x}$ & $\mathrm{x}$ \\
\hline $\begin{array}{l}\text { Myrmecozela lambessella s. str. ReBEL, } 1901 \\
\text { [= lambesella } \text { REBEL, 1901, lapsus calami] }\end{array}$ & $\mathrm{x}$ & - & $\mathrm{x}$ & $\mathrm{x}$ \\
\hline Edosa lardatella (LEDERER, 1858) & - & $\mathrm{x}$ & $\mathrm{x}$ & $\mathrm{x}$ \\
\hline $\begin{array}{l}\text { Perissomastix (Perissomastix) biskraella }(\text { Rebel, 1901) } \\
\text { [= intermediella Turati, 1926, nec Petersen, 1961; = dernaella Turati, 1926; = abscon- } \\
\text { dita Gozmany, 1960] }\end{array}$ & $\mathrm{x}$ & $\mathrm{x}$ & $\mathrm{x}$ & $\mathrm{x}$ \\
\hline $\begin{array}{l}\text { Crassicornella agenjoi (PETERSEN, 1957) } \\
\text { [= crassicornella Agenjo, 1952, nec ZelLer, 1847; = incerta GozmánY, 1960] }\end{array}$ & $\mathrm{x}$ & $\mathrm{x}$ & $\mathrm{x}$ & $\mathrm{x}$ \\
\hline Crassicornella hirundinea (MeYrICK, 1928), nec ZernY, 1935 & - & $\mathrm{x}$ & - & - \\
\hline $\begin{array}{l}\text { Crassicornella zernyi (PETERSEN, 1957) } \\
\text { [= hirundinea ZeRNY, 1935, nec MeYRICK, 1928; = perplexa GozMANY, 1960; = atlantis } \\
\text { ZAGULAJEV, 1975, syn. nov.] }\end{array}$ & - & $\mathrm{x}$ & - & - \\
\hline Crassicornella bifurcatella (PetERSEN, 1957) & - & - & - & $\mathrm{x}$ \\
\hline $\begin{array}{l}\text { Ateliotum petrinellum s. str. (HERRICH-SCHÄFFER, 1854) } \\
\text { [= turatiella MillìkRE, 1885] }\end{array}$ & - & - & - & $\mathrm{x}$ \\
\hline Cephimallota vittatella (CHRÉTIEN, 1915) & - & - & - & $\mathrm{x}$ \\
\hline Cephimallota tunesiella (ZaGulajev, 1966) & - & $\mathrm{x}$ & $\mathrm{x}$ & $\mathrm{x}$ \\
\hline $\begin{array}{l}\text { Cephimallota repetekiella (ZAGULAJEv, 1971) } \\
\text { [= striatella LuCAS, 1942, nec DeNIS \& SCHIFFERMÜLLER, 1775; = tunusensis KoCAK, } \\
\text { 1981] }\end{array}$ & - & - & $\mathrm{x}$ & - \\
\hline Ceratuncus maroccanellus (AMsEL, 1951) & - & $\mathrm{x}$ & - & - \\
\hline Reisserita bettagi sp. $\mathrm{n}$. & - & $\mathrm{x}$ & - & - \\
\hline Reisserita stengeli sp. $\mathrm{n}$. & - & $\mathrm{x}$ & - & - \\
\hline
\end{tabular}




\begin{tabular}{|c|c|c|c|c|}
\hline Taxon & Maur. & Mor. & Alg. & Tun. \\
\hline Reisserita chalcopterella (ZERNY, 1935) & - & $\mathrm{x}$ & - & - \\
\hline Reisserita luteopterella Petersen, 1957 & - & $\mathrm{x}$ & - & - \\
\hline Reisserita karsholti sp. $\mathrm{n}$. & - & $\mathrm{x}$ & - & - \\
\hline Reisserita parva Petersen \& Gaedike, 1979 & - & $\mathrm{x}$ & - & - \\
\hline Reisserita oranella PeTERSEN, 1957 & - & - & $\mathrm{x}$ & - \\
\hline Reisserita pseudoranella Petersen \& Gaedike, 1979 & - & $\mathrm{x}$ & - & - \\
\hline Reisserita panormitanella (MANN, 1859) & - & - & $\mathrm{x}$ & $\mathrm{x}$ \\
\hline $\begin{array}{l}\text { Reisserita mauritanica (BAKER, 1885) } \\
{[=\text { melitensis AMSEL, 1951] }}\end{array}$ & - & - & $\mathrm{x}$ & $\mathrm{x}$ \\
\hline 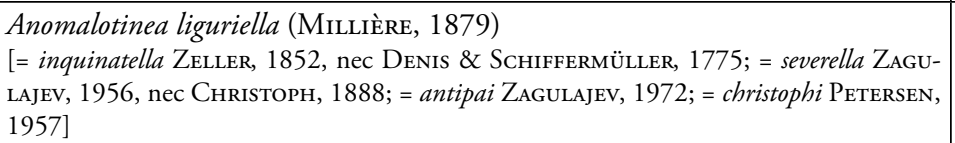 & - & - & $\mathrm{x}$ & $\mathrm{x}$ \\
\hline $\begin{array}{l}\text { Anomalotinea leucella (TURATI, 1926) } \\
\text { [= strioligera TuratI, 1926; = leucelloides AMSEL, 1935; = balchanella ZAGULAJEV, 1956] }\end{array}$ & - & - & $\mathrm{x}$ & $\mathrm{x}$ \\
\hline $\begin{array}{l}\text { Anomalotinea paepalella (WALSINGHAM, 1907) } \\
\text { [= nigropilella CHRÉTIEN, 1915] }\end{array}$ & - & $\mathrm{x}$ & $\mathrm{x}$ & $\mathrm{x}$ \\
\hline $\begin{array}{l}\text { Anomalotinea fulvescentella (LUCAS, 1956) } \\
{[=\text { maroccana PETERSEN \& GAEDIKE, 1979] }}\end{array}$ & - & $\mathrm{x}$ & - & - \\
\hline $\begin{array}{l}\text { Anomalotinea chellalalis (REBEL, 1901) } \\
{[=\text { cuencella CARADJA, 1920] }}\end{array}$ & - & - & $\mathrm{x}$ & - \\
\hline Anomalotinea wernoi sp. $\mathrm{n}$. & - & $\mathrm{x}$ & - & - \\
\hline Anomalotinea derrai sp. $\mathrm{n}$. & - & $\mathrm{x}$ & - & - \\
\hline $\begin{array}{l}\text { Anomalotinea cubiculella algiricella (REBEL, 1901) } \\
\text { [= occidentalis ZAGULAJEV, 1972] }\end{array}$ & $\mathrm{x}$ & - & $\mathrm{x}$ & $\mathrm{x}$ \\
\hline $\begin{array}{l}\text { Anomalotinea cubiculella romei (TuRATI, 1930) } \\
\text { [= eremica AMSEL, 1935] }\end{array}$ & - & - & - & $\mathrm{x}$ \\
\hline $\begin{array}{l}\text { Trichophaga tapetzella } \text { (LinNAEUs, 1758) } \\
\text { [= palaestrica } \text { BuTLER, 1877] }\end{array}$ & - & - & $\mathrm{x}$ & $\mathrm{x}$ \\
\hline $\begin{array}{l}\text { Trichophaga bipartitella (RAGONOT, 1892) } \\
\text { [= amina MEYRICK, 1925; = desertella MABILLE, 1907] }\end{array}$ & $\mathrm{x}$ & $\mathrm{x}$ & $\mathrm{x}$ & $\mathrm{x}$ \\
\hline $\begin{array}{l}\text { Trichophaga robinsoni GaEDIKE \& KaRSHOLT, } 2001 \\
\text { [= abruptella Wollaston, 1858, nec ThUNBERG, 1794] }\end{array}$ & - & $\mathrm{x}$ & - & - \\
\hline Ceratophaga infuscatella (JoAnNIs, 1897) & $\mathrm{x}$ & $\mathrm{x}$ & $\mathrm{x}$ & $\mathrm{x}$ \\
\hline $\begin{array}{l}\text { Elatobia fuliginosella } \text { (LIENIG \& ZELLER, 1846) } \\
\text { [= martinella } \text { WaLKER, 1863; = carbonella DIETZ, 1905; = kenteella STAUDINGER, 1892; } \\
=\text { severella } \text { CHRISTOPH, 1888] }\end{array}$ & - & $\mathrm{x}$ & - & $\mathrm{x}$ \\
\hline $\begin{array}{l}\text { Xerantica tephroclysta MEYRICK, } 1930 \\
{[=\text { trichophagoides ZERNY, 1935] }}\end{array}$ & - & $\mathrm{x}$ & - & - \\
\hline $\begin{array}{l}\text { Tineola bisselliella } \text { (HUMmeL, 1823) } \\
\text { [= flavifrontella THUNBERG, 1794; = crinella SODOFFSKY, 1830; = destructor } \text { STEPHENS, } \\
\text { 1834; = lanariella CLEMENS, 1859; = furciferella ZAGULAJEv, 1954; = anaphecola Goz- } \\
\text { MÁNY, 1967] }\end{array}$ & - & $\mathrm{x}$ & - & $\mathrm{x}$ \\
\hline $\begin{array}{l}\text { Tinea murariella STAUDINGER, } 1859 \\
{[=\text { bipunctella } \text { RAGONOT, } 1874]}\end{array}$ & - & $\mathrm{x}$ & $\mathrm{x}$ & $\mathrm{x}$ \\
\hline Tinea messalina RoBInson, 1979 & - & - & $\mathrm{x}$ & - \\
\hline $\begin{array}{l}\text { Tinea translucens MeYRICK, } 1917 \\
\text { [= metonella Pierce \& METCALFE, 1934; = leonhardi PETERSEN, 1957; = margaritacea } \\
\text { GozMÁNY, 1968; = fortificata GoZMÁNY, 1968] }\end{array}$ & - & - & - & $\mathrm{x}$ \\
\hline
\end{tabular}




\begin{tabular}{|c|c|c|c|c|}
\hline Taxon & Maur. & Mor. & Alg. & Tun. \\
\hline $\begin{array}{l}\text { Tinea dubiella STAINTON, } 1859 \\
\text { [= turicensis MÜLLER-RUTZ, 1920; = bispinella ZAGULAJEV, 1960; = tenerifi ZAGULAJEV, } \\
\text { 1966] }\end{array}$ & - & $x$ & $\mathrm{x}$ & - \\
\hline $\begin{array}{l}\text { Tinea flavescentella } \text { HawORTH, } 1828 \\
{[=\text { tristigmatella } \text { CostA, } 1836]}\end{array}$ & - & - & $\mathrm{x}$ & - \\
\hline $\begin{array}{l}\text { Tinea basifasciella } \text { RAGONOT, } 1895 \\
\text { [= punctigera WALSINGHAM, 1907; = nitentella CHRÉTIEN, 1908; = punctigera palaestinel- } \\
\text { la AMSEL, 1955; = exquisita GOZMÁNY, 1960] }\end{array}$ & - & $\mathrm{x}$ & $\mathrm{x}$ & $\mathrm{x}$ \\
\hline 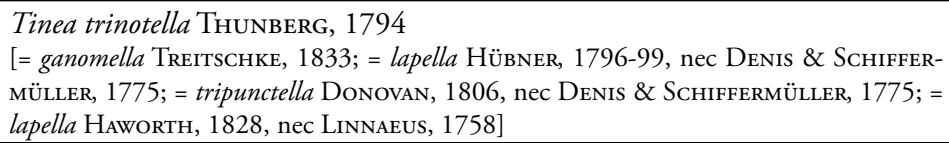 & - & - & $\mathrm{x}$ & - \\
\hline 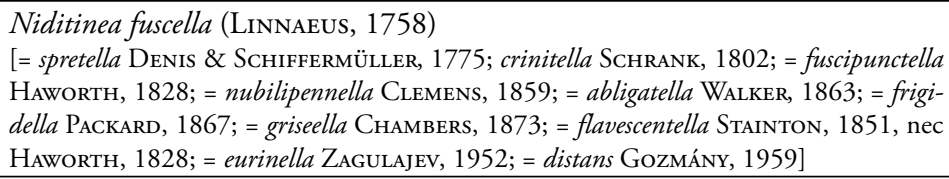 & - & $\mathrm{x}$ & $\mathrm{x}$ & $\mathrm{x}$ \\
\hline $\begin{array}{l}\text { Niditinea tugurialis (MEYRICK, 1932) } \\
\text { [= unipunctella ZAGULAJEV, 1960; = baryspilas MeYRICK, 1937] }\end{array}$ & - & - & - & $\mathrm{x}$ \\
\hline $\begin{array}{l}\text { Proterospastis merdella (ZELLER, 1852) } \\
\text { [= siccanella CHRÉTIEN, 1915; = palaestinella AMSEL, 1935; = atriensis MEYRICK, 1925] }\end{array}$ & - & - & $\mathrm{x}$ & - \\
\hline Proterospastis autochthones (WALSINGHAM, 1907) & - & - & $\mathrm{x}$ & $\mathrm{x}$ \\
\hline Proterospastis ellipticella (CHRÉTIEN, 1915) & - & - & - & $\mathrm{x}$ \\
\hline Proterospastis tripolitella (REBEL, 1908) & - & - & $\mathrm{x}$ & $\mathrm{x}$ \\
\hline $\begin{array}{l}\text { Monopis laevigella (DENIS \& SCHIFFERMÜLLER, 1775) } \\
\text { [= rusticella HüBNER, 1810-13, nec HüBNER, 1796; = vestianella STEPHENs, 1835] }\end{array}$ & - & - & - & $\mathrm{x}$ \\
\hline $\begin{array}{l}\text { Monopis crocicapitella (CLEMENS, 1859) } \\
\text { [= hyalinella STAUDINGER, 1870; = lombardica HeRING, 1889; = ferruginella DyAR, 1902, } \\
\text { nec HÜBNER, 1813; = cecconii TuRATI, 1919; = dobrogica GEORGESCU, 1964] }\end{array}$ & - & $\mathrm{x}$ & - & - \\
\hline $\begin{array}{l}\text { Monopis imella (HÜBNER, 1813) } \\
{[=\text { nitidella ZAGULAJEV, 1960] }}\end{array}$ & - & $\mathrm{x}$ & $\mathrm{x}$ & $\mathrm{x}$ \\
\hline Monopis nigricantella (MiLlıèRE, 1872) & - & $\mathrm{x}$ & - & $\mathrm{x}$ \\
\hline Amphixystis maroccana sp. $\mathrm{n}$. & - & $\mathrm{x}$ & - & - \\
\hline
\end{tabular}

\section{References}

Robinson, G. S. 1980: The Himalayan Nemapogoninae (Lepidoptera: Tineidae), with a note on the female of Nemapogon levantinus Petersen. - Entomologist's Gazette 31: 129-142, 11 Figs.

Zagulajev, A. K. 1975: Nastojaschtschije moli (Tineidae), Podsemejstvo Myrmecozelinae. - In: Fauna SSSR, N. S. 108. Nasekomyje, Tscheschujekrylyje. - Leningrad 4 (5): 1-428, 319 Figs.

Author's address:

Dr. Reinhard Gaedike

Florusstraße 5

53225 Bonn, Germany

e-mail: tinagma@msn.com
Subject editor:

Dr. M. Nuss 


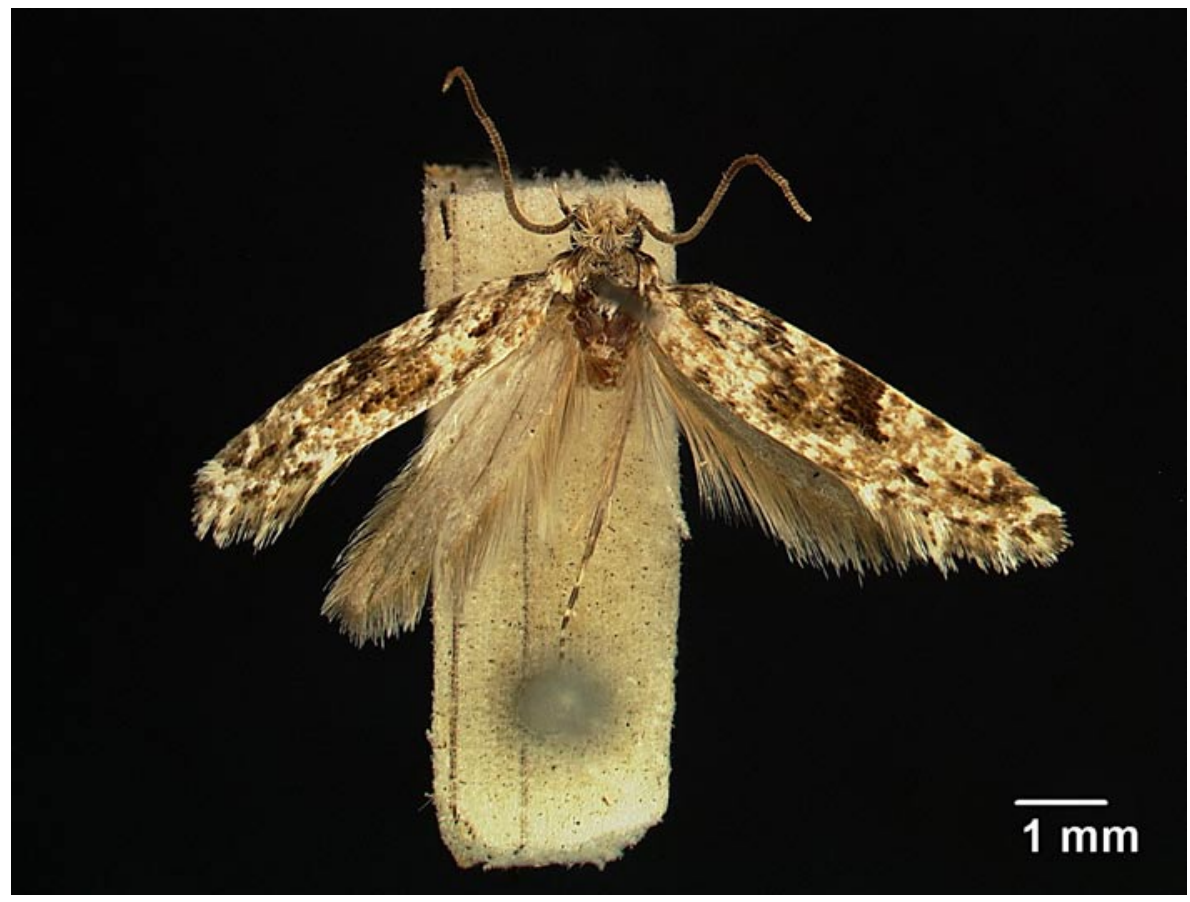

Fig. 1: Nemapogon algerica sp. $\mathrm{n}$.

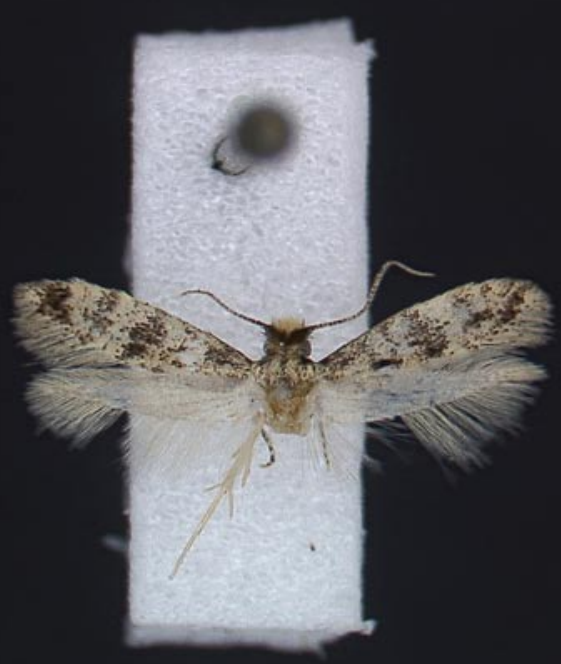

$2 \mathrm{~mm}$

Fig. 2: Infurcitinea italicoides sp. n. 


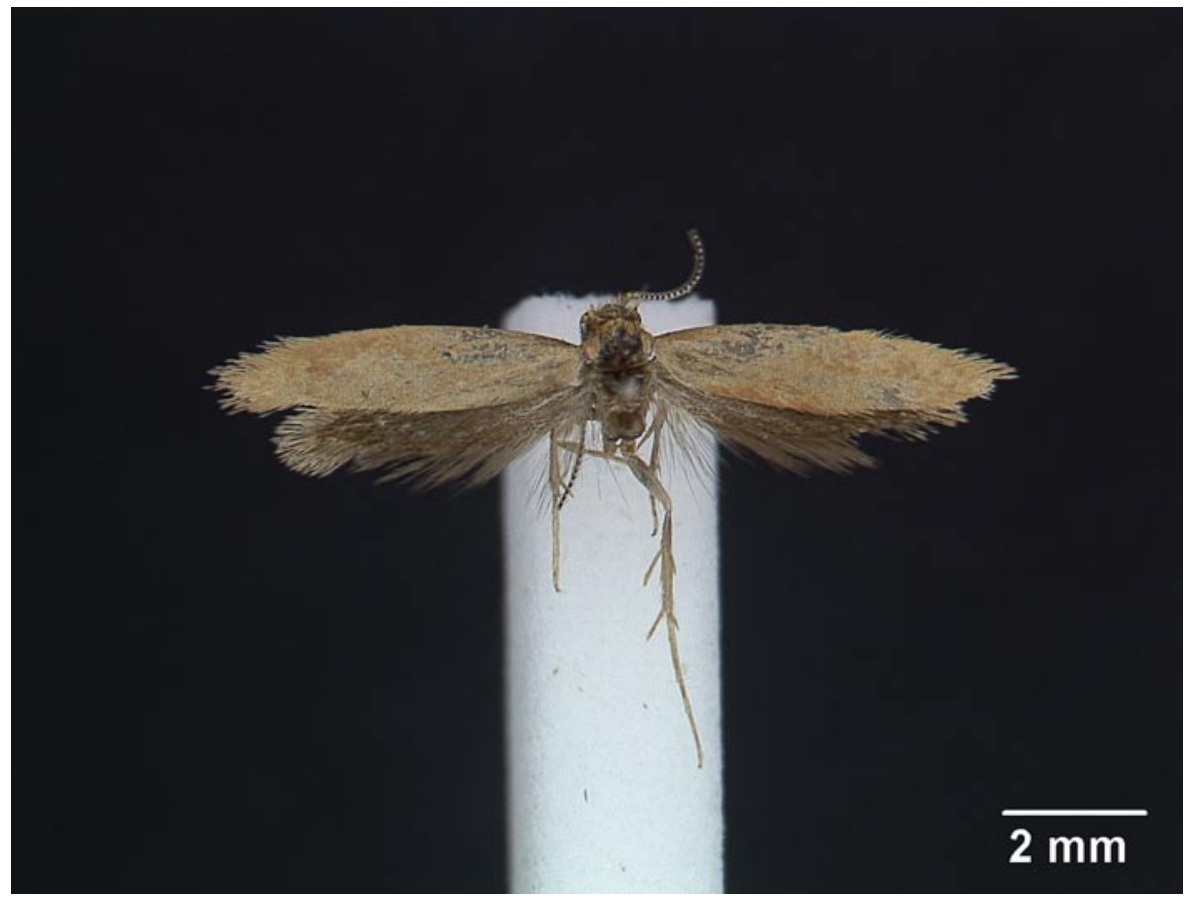

Fig. 3: Reisserita bettagi sp. n.

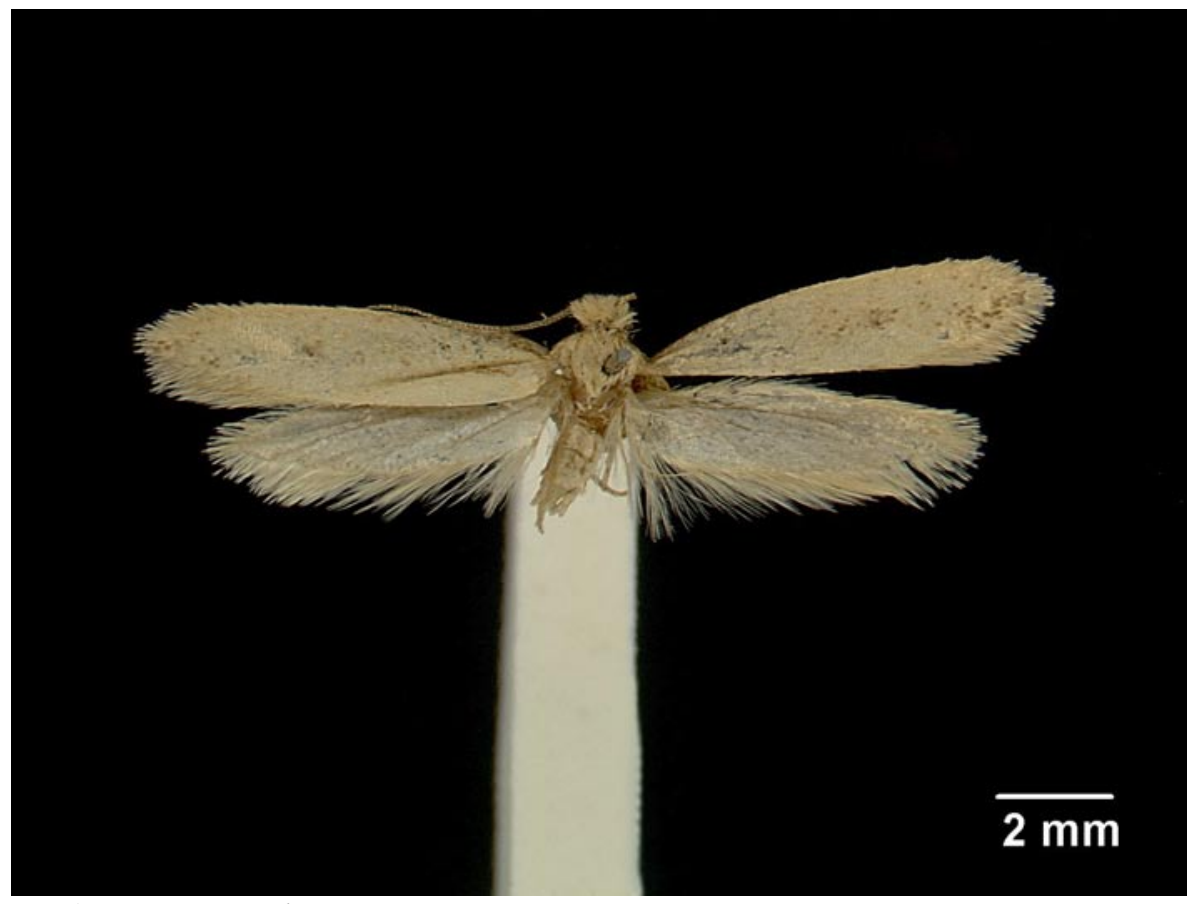

Fig. 4: Reisserita stengeli sp. $\mathrm{n}$. 


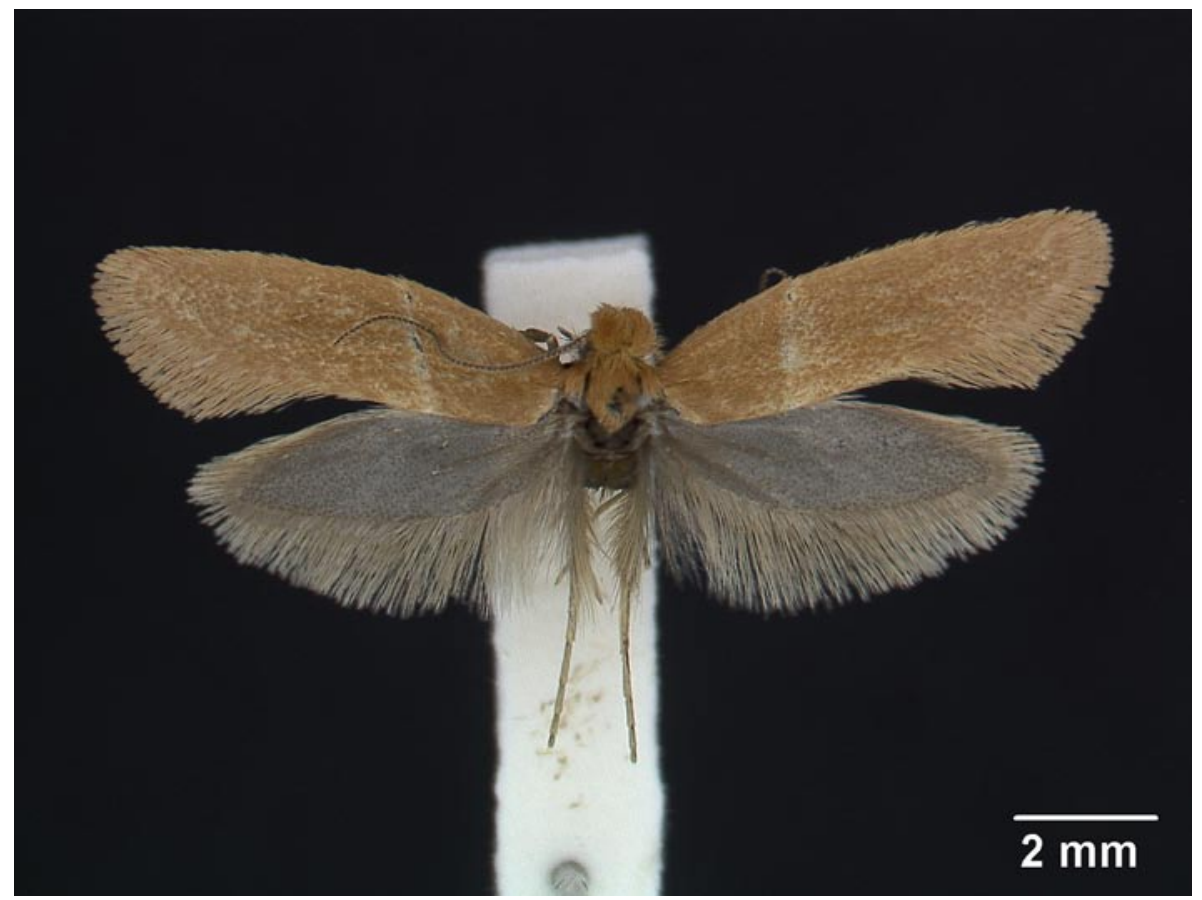

Fig. 5: Reisserita karsholti sp. n.

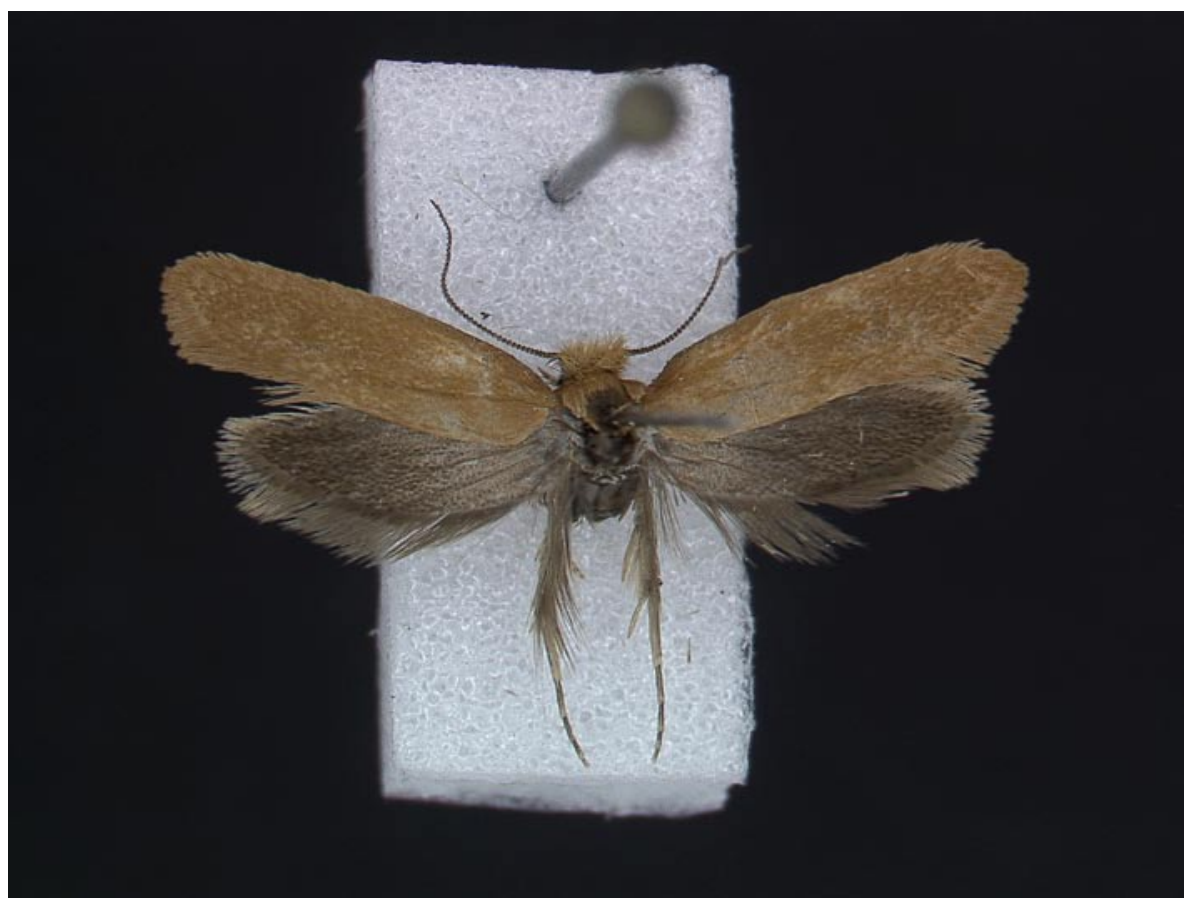

Fig. 6: Anomalotinea wernoi sp. n. 


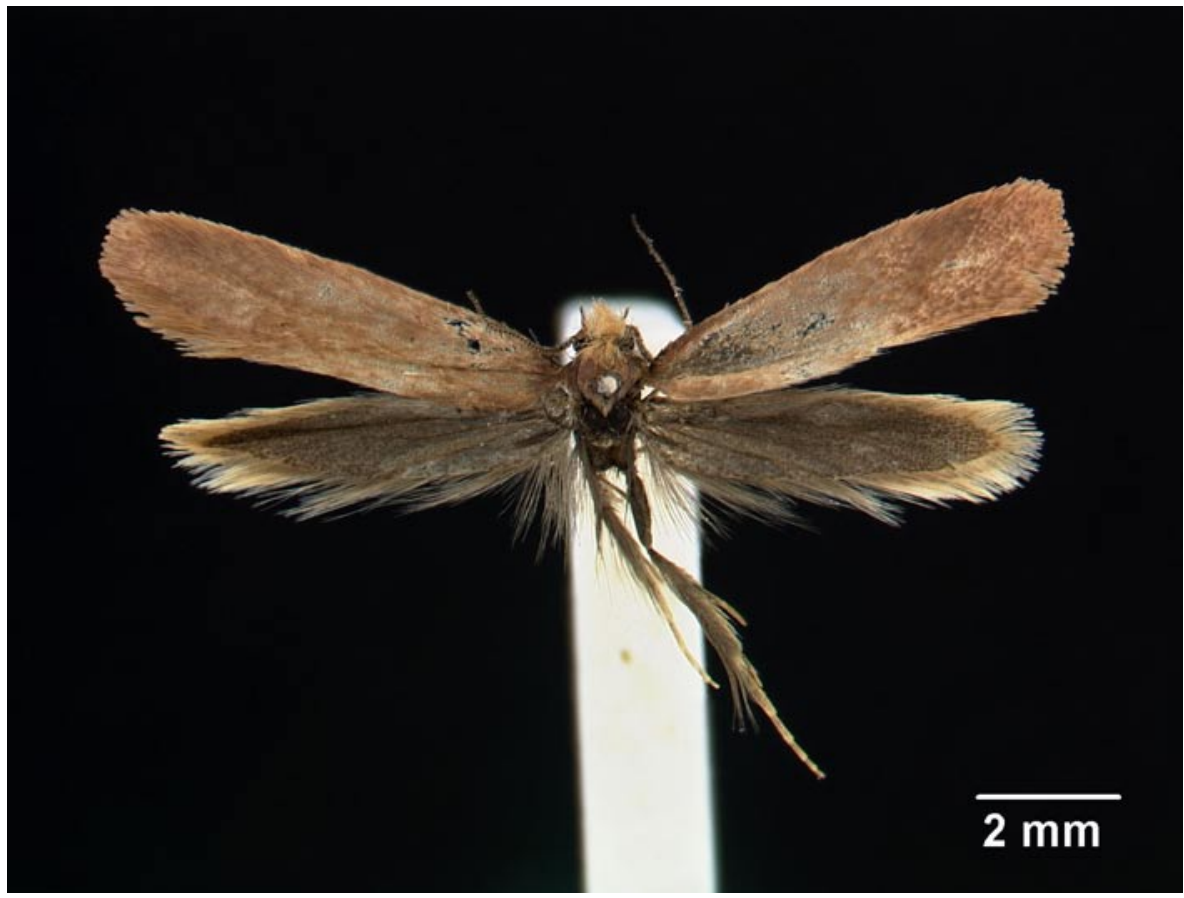

Fig. 7: Anomalotinea derrai sp. n.

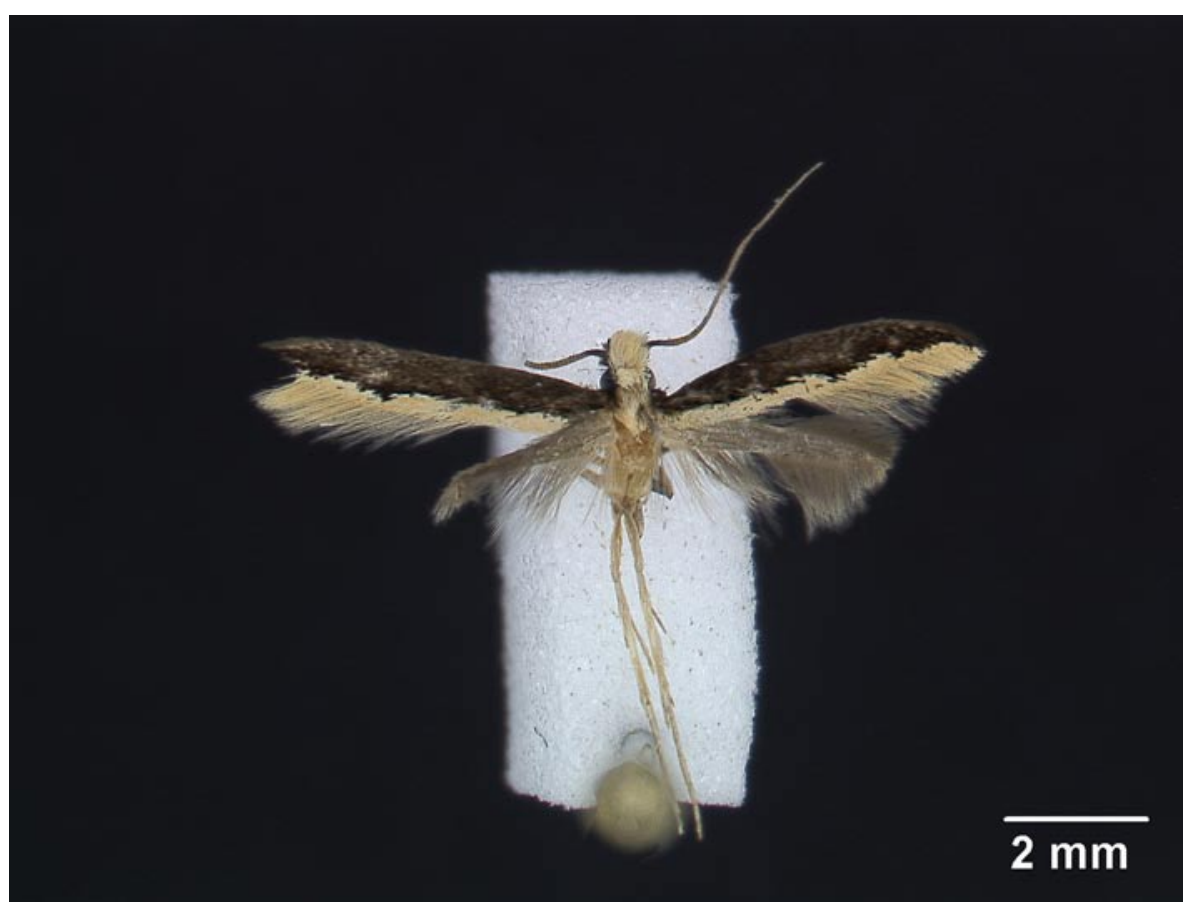

Fig. 8: Amphixystis maroccana sp. n. 

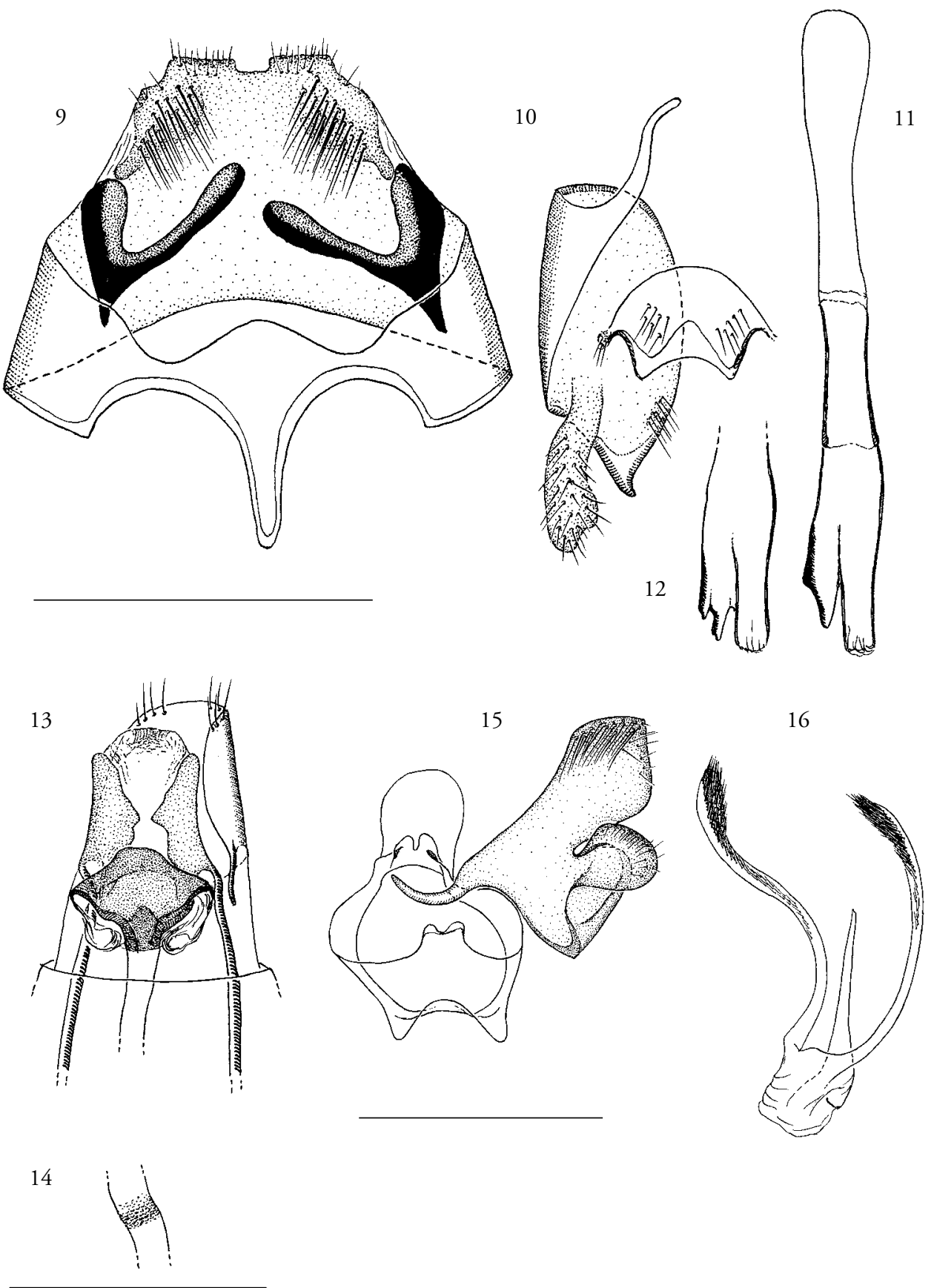

Figs 9-14: Nemapogon algerica ơ: (9: uncus-tegumen-saccus - 10: valva and anellus - 11-12: phallus with variability in the tooth-like processus), $\odot:$ (13: VIII segment and ostium - 14: scale-shaped sclerotizations in ductus bursae).

Figs 15-16: Infurcitinea italicoides $\sigma^{\star}$ : (15: genitalia, one valva removed - 16: phallus-anellus). 

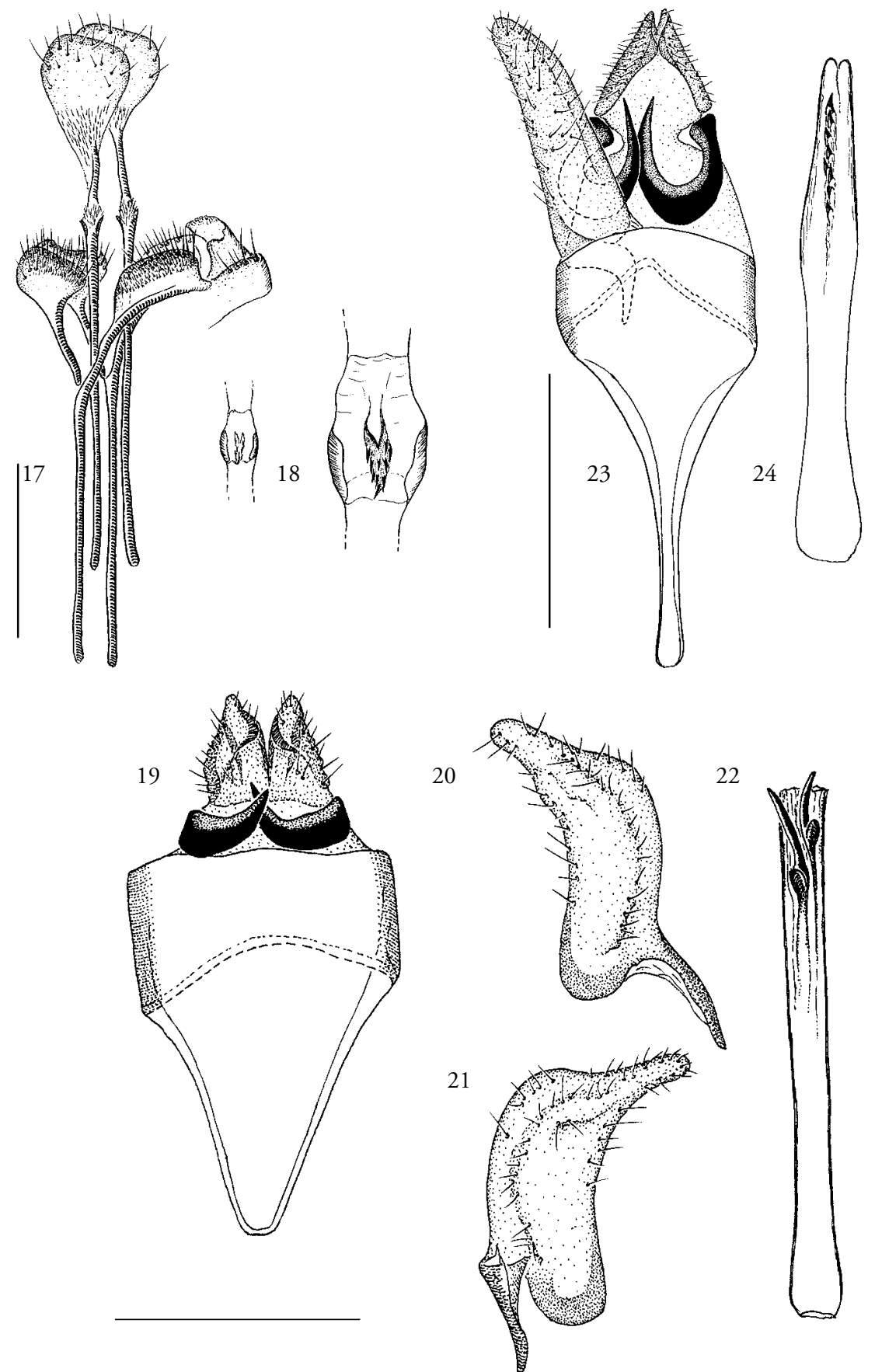

Figs 17-18: Crassicornella zernyi 우 (17: anterior and posterior apophyses, ostium - 18: sclerotization in ductus bursae, enlarged).

Figs 19-22: Reisserita bettagi o : (19: uncus-tegumen-complex - 20, 21: valvae - 22: phallus).

Figs 23-24: Reisserita stengeli ơ: (23: genitalia, one valve removed - 24: phallus). 


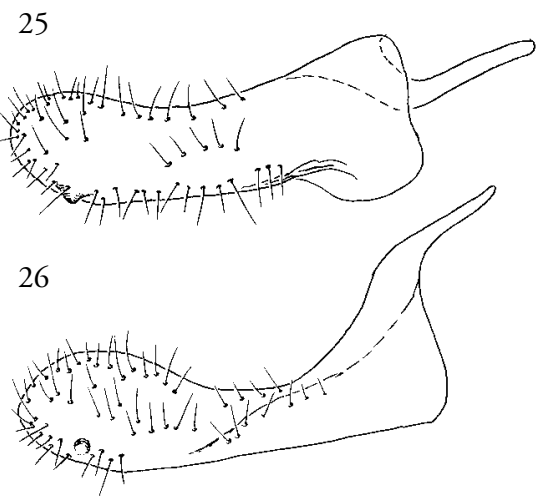

27

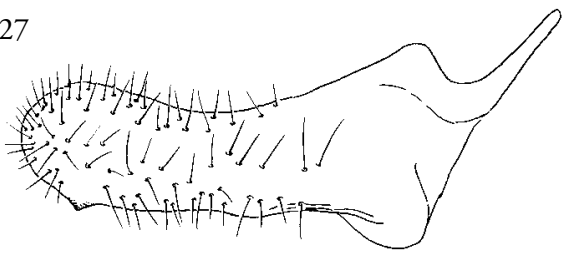

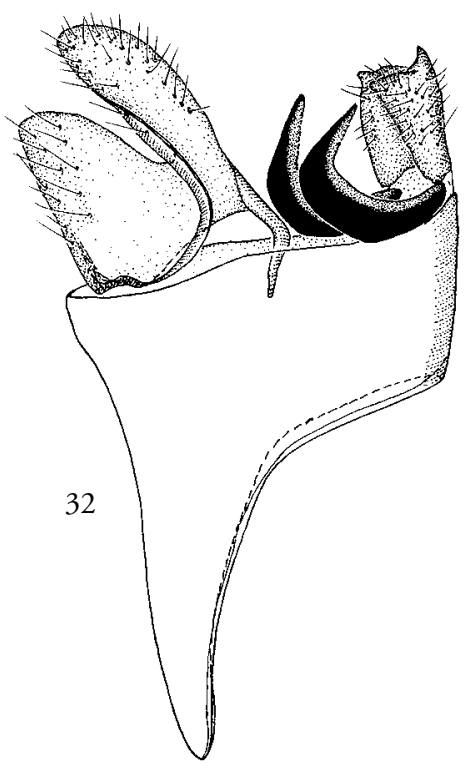
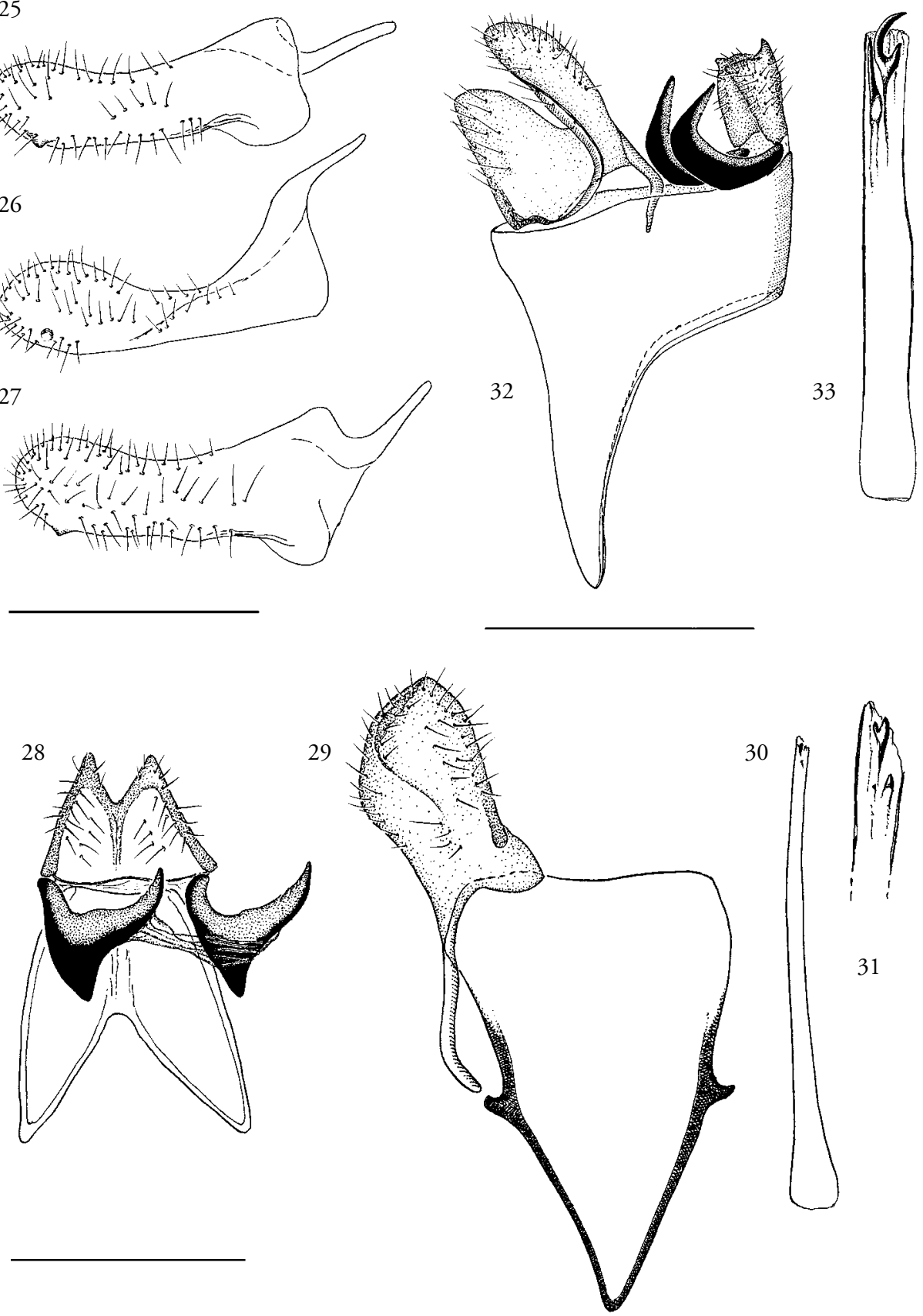

Figs 25-27: Reisserita chalcopterella ơ: (25-27: variability of valvae).

Figs 28-31: Reisserita karsholti ${ }^{*}$ : (28: uncus-tegumen - 29: saccus and valva - 30: phallus - 31: tip of phallus, enlarged).

Figs 32-33: Anomalotinea wernoi ơ: (32: genitalia, one valva removed - 33: phallus). 

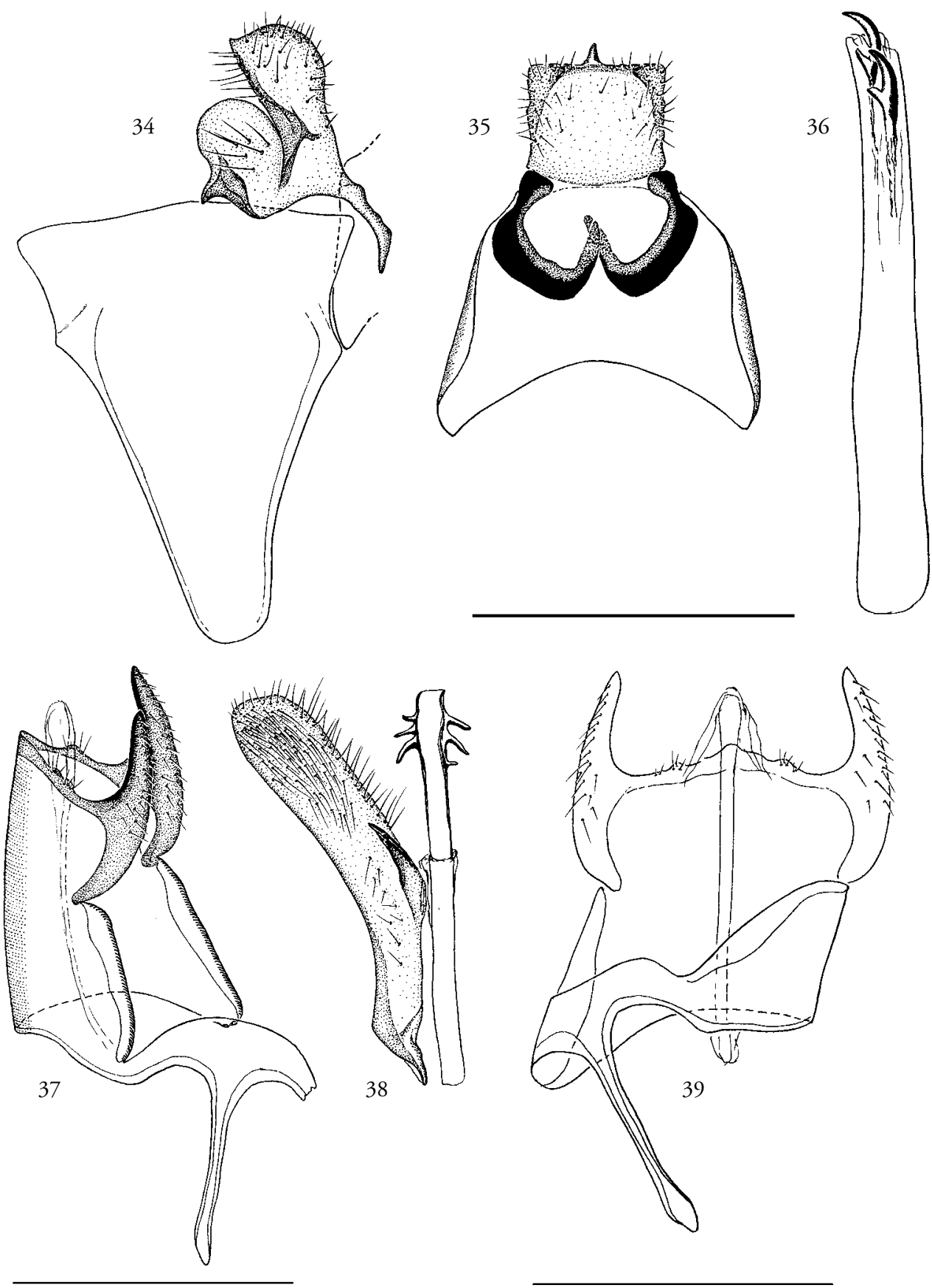

Figs 34-36: Anomalotinea derrai, $0^{*}$ : (34: Saccus and valva - 35: uncus-tegumen - 36: phallus).

Figs 37-39: Amphixystis maroccana, $0^{*}$ : (37: uncus-tegumen-saccus - 38: valva and phallus - 39: uncus-tegumen-saccus, ventral view). 

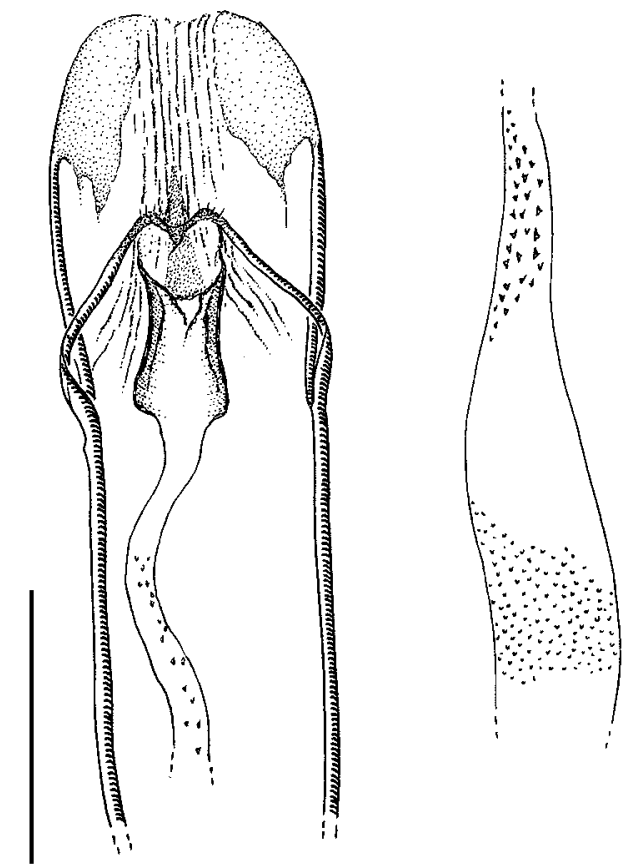

Figs 40-41: Amphixystis maroccana, ơ: (40: anterior apophyses with antrum. - 41: last part of ductus bursae). 